\title{
Vitamin D and Vitiligo
}

\author{
Sang Ho Oh and Miri Kim \\ Department of Dermatology $\mathcal{E}$ Cutaneous Biology Research Institute \\ Yonsei University College of Medicine, Seoul \\ Korea
}

\section{Introduction}

Vitamin D is a steroid hormone with such pleiotropic effects as bone and calcium homeostasis, as well as immunomodulation, and it exerts its effects via the vitamin D receptor (VDR). Vitamin D can be obtained from food as vitamin $\mathrm{D}_{3}$ (cholecalciferol), but is also synthesized in the keratinocytes in the epidermis from the precursor molecule 7dehydrocholesterol (provitamin D3) by ultraviolet B (UVB) radiation in sunlight to previtamin D3. Pre-vitamin $\mathrm{D}_{3}$ then undergoes a spontaneous, temperature-dependent isomerization to vitamin $\mathrm{D}_{3}$ (cholecalciferol), which enters the dermal capillaries. At this point, endogenous vitamin $D_{3}$ and exogenous dietary $D_{2}$ (ergocalciferol) undergo hydroxylation in the liver to 25-hydroxy Vitamin D (calcitriol). This molecule travels to the kidney where it is again hydroxylated to make mature vitamin $\mathrm{D}(1,25$-dihydroxy Vitamin $\mathrm{D}$, or $1,25(\mathrm{OH})_{2} \mathrm{D}_{3}$, which is also known as calcitriol) and 24,25-dihydroxyvitamin D. $1,25(\mathrm{OH})_{2} \mathrm{D}_{3}$ is the biologically active form of vitamin $\mathrm{D}$, which regulates serum calcium and phosphate homeostasis.(Klaus Wolff 2008) Circulating $1,25(\mathrm{OH})_{2} \mathrm{D}_{3}$ has a very short half-life and is tightly regulated by parathyroid hormone. Fibroblast growth factor 23 (FGF23), which is produced in osteoblasts, is also important in regulating $1,25(\mathrm{OH})_{2} \mathrm{D}_{3}$ production in the kidney.(Jurutka, Bartik et al. 2007)

\section{Vitamin $D$ and autoimmune diseases}

There is increasing evidence that vitamin D may have an immunoregulatory role in various autoimmune diseases. The mechanism by which vitamin $\mathrm{D}$ affects autoimmunity is unknown, but there is clear evidence of regulation of immune cells by vitamin $\mathrm{D}$ in vitro.(Adorini and Penna 2008; Cantorna, Yu et al. 2008) Vitamin D has multiple effects on innate and adaptive immune responses through its effects on $\mathrm{T}$ and $\mathrm{B}$ lymphocytes, macrophages, and dendritic cells (DC), all of which express the VDR.(Adorini and Penna 2008) High levels of $1,25(\mathrm{OH})_{2} \mathrm{D}_{3}$ inhibit dendritic cell maturation with lower expression of major histocompatibility complex (MHC) class II molecules, downregulation of costimulatory molecules that are required for antigen presentation, and lower production of proinflammatory cytokines such as interleukin (IL)-12.(van Etten and Mathieu 2005; Baeke, van Etten et al. 2008) In mouse models, $1,25(\mathrm{OH})_{2} \mathrm{D}_{3}$ drives the adaptive immune system from a $T$ helper $T_{h} 1 / T_{h} 17$ response toward a $T_{h} 2$ and regulatory $T$-cell response, suggesting the potential beneficial effects of vitamin $\mathrm{D}$ on the inhibition of $\mathrm{T}_{\mathrm{h}} 1$-mediated autoimmune 
diseases in humans.(Daniel, Sartory et al. 2008) The immune system of VDR-deficient mice is grossly normal but shows increased susceptibility to autoimmune diseases such as inflammatory bowel disease and type 1 diabetes mellitus.(Bouillon, Carmeliet et al. 2008) In addition, $1,25(\mathrm{OH})_{2} \mathrm{D}_{3}$ may suppress autoimmune diseases by enhancing the production and function of regulatory $\mathrm{T}$ cells (Tregs), which are vital for preserving peripheral selftolerance. $1,25(\mathrm{OH})_{2} \mathrm{D}_{3}$ plays a role in the activation of Tregs by DCs, by increasing the number of Tregs, and enhancing their secretion of IL-10, which inhibits the activation of T lymphocytes.(Loser, Mehling et al. 2006; Spach, Nashold et al. 2006) There is some evidence that vitamin D may play a regulatory role in autoantibody production by B cells, inhibiting the ongoing proliferation of activated B cells and inducing their apoptosis.(Chen, Sims et al. 2007) Several mechanisms have been proposed to explain the role for vitamin D insufficiency in the pathogenesis of autoimmune disorders.

There are also various reports of vitamin D deficiency associated with several autoimmune disorders, including inflammatory bowel disease, multiple sclerosis (MS), systemic lupus erythematosus (SLE), type 1 diabetes mellitus, and rheumatoid arthritis (RA).(Cantorna, Yu et al. 2008) Furthermore, vitamin D polymorphisms have also been associated with increased risk of multiple autoimmune diseases, including Hashimoto's thyroiditis, inflammatory bowel disease, Graves' disease, rheumatoid arthritis, SLE, primary biliary cirrhosis (PBC), autoimmune hepatitis, Addison's disease, vitiligo, celiac disease, type I diabetes mellitus and multiple sclerosis (MS).(Kriegel, Manson et al. 2011) Therefore, supplementation of vitamin D can possibly be used as a treatment in autoimmune disease. Vitamin D supplementation has been shown to be therapeutically effective in different experimental animal models, such as allergic encephalomyelitis, collagen-induced arthritis, type 1 diabetes mellitus, inflammatory bowel disease, autoimmune thyroiditis, and systemic lupus erythematosus.(Lemire and Archer 1991; Mathieu, Waer et al. 1994; Cantorna, Hayes et al. 1998; Cantorna, Munsick et al. 2000; Van Etten, Branisteanu et al. 2003) However, despite the in vitro and animal evidence for the promising effects of vitamin $\mathrm{D}$ to decrease systemic inflammation and prevent autoimmune disease in humans, these findings have been somewhat conflicting in humans.

\section{Association between vitamin $D$ and vitiligo}

Vitiligo, an autoimmune pigmentary disorder, is characterized by the aberrant loss of functional melanocytes from involved epidermis. The association of vitiligo with autoimmune conditions is well-established. Vitiligo is commonly associated with thyroid disorders and abnormalities, particularly Hashimoto's thyroiditis and Grave's disease, type I diabetes mellitus, and Sjögren's syndrome.(Sehgal, Rege et al. 1976; Niepomniszcze and Amad 2001; Montes, Pfister et al. 2003; Adorini and Penna 2008) Low levels of vitamin D have also been associated with autoimmune diseases, including rheumatoid arthritis, type I diabetes mellitus, and multiple sclerosis.(Adorini and Penna 2008) However, little is known about the association of vitiligo and reduced vitamin D levels.

Silverberg et al. reported that patients with vitiligo who have low levels of vitamin D were at higher risk for secondary forms of autoimmunity and that insufficient vitamin D levels were associated with increasing Fitzpatrick phototype.(Silverberg, Silverberg et al. 2010) They suggested that monitoring vitamin D levels in patients with vitiligo may identify individuals at greater risk for secondary autoimmune diatheses. However, there is no reliable evidence that vitamin D supplementation can treat or prevent vitiligo. 


\section{Effect of topical vitamin $D$ on vitiligo}

In recent years, topical vitamin D analogues, particularly calcipotriol and tacalcitol, have been used as monotherapy or in combination with phototherapy for the treatment of vitiligo. Even if their exact mechanism of actions were unclear, vitamin D analogues have two different effects on vitiligo in terms of immune function and melanocytes. Vitamin D ligands are designed to target the local immune response in vitiligo, acting specifically on $\mathrm{T}$ cell activation, mainly by inhibiting the transition of $T$ cells from the early-to-late $\mathrm{G}_{1}$ period in interphase and by inhibiting the expression of several pro-inflammatory cytokines genes, such as those encoding tumor necrosis factor-alpha (TNF- $\alpha$ ) and interferon gamma (IFN- $\gamma$ ). Vitamin $\mathrm{D}_{3}$ compounds are known to influence melanocyte maturation and differentiation and also to up-regulate melanogenesis through pathways activated by specific ligand receptors, such as the endothelin receptor and the proto-oncogene c-kit (mast/stem cell growth factor receptor [SCFR]).(Birlea, Costin et al. 2008)

At the molecular level, the addition of vitamin D compounds to a vitiligo treatment regimen along with different forms of UV and glucocorticoids can halt disease progression in vitiligo by immunosuppression and possibly induce repigmentation by activating melanocyte precursors and the promotion of melanogenic pathways.(Birlea, Costin et al. 2009)

However, the true effects of vitamin D analogues on vitiligo remain controversial (Table 1). Some studies have reported a good response or even an augmented response to them over conventional vitiligo therapies, whereas other studies have reported no response to or only limited effects of vitamin D analogues.(Leone, Pacifico et al. 2006; Lu-yan, Wen-wen et al. 2006; Goldinger, Dummer et al. 2007; Rodriguez-Martin, Garcia Bustinduy et al. 2009) One of the authors (SHO) published a prospective study which showed that the use of high concentration tacalcitol had a limited effect as either monotherapy or as part of combination therapy with excimer laser in the treatment of vitiligo.(Oh, Kim et al. 2011)

\begin{tabular}{|c|c|c|c|c|c|}
\hline Treatment & $\begin{array}{c}\text { Type of } \\
\text { Vitamin D }\end{array}$ & $\begin{array}{l}\text { Study } \\
\text { design }\end{array}$ & Results & Effect & |References \\
\hline \begin{tabular}{|l} 
Tacalcitol \\
ointment \\
$(4 \mu \mathrm{g} / \mathrm{g})+30 \mathrm{~min}$ \\
sunlight daily \\
vs placebo + \\
sunlight \\
\end{tabular} & Tacalcitol & $\begin{array}{l}\text { Randomized, } \\
\text { double- } \\
\text { blinded, } \\
\text { placebo- } \\
\text { controlled }\end{array}$ & $\begin{array}{l}\text { Placebo+heliotherapy: } \\
1 / 31 \\
\text { Tacalcitol+heliothera } \\
\text { py: } 0 / 32>75 \% \\
\text { repigmentaton after } 4 \\
\text { months }\end{array}$ & No & \begin{tabular}{||l} 
(Rodriguez \\
-Martin, \\
Garcia \\
Bustinduy \\
et al. 2009)
\end{tabular} \\
\hline $\begin{array}{l}\text { NB-UVB vs NB- } \\
\text { UVB+ tacalcitol } \\
(4 \mu \mathrm{g} / \mathrm{g})\end{array}$ & Tacalcitol & \begin{tabular}{|l|} 
Randomized, \\
investigator \\
blinded, \\
controlled, \\
left-right \\
trial
\end{tabular} & $\begin{array}{l}\text { NB-UVB: } 0 / 32 \\
\text { NB-UVB+tacalcitol: } \\
16 / 32(50 \%)>80 \% \\
\text { repigmentation after } \\
6 \text { months }\end{array}$ & Yes & \begin{tabular}{||l}
$($ Leone, \\
Pacifico \\
et al. 2006)
\end{tabular} \\
\hline $\begin{array}{l}\text { Excimer light } \\
\text { once weekly+ } \\
\text { placebo vs } \\
\text { excimer } \\
\text { light+tacalcitol } \\
(2 \mu \mathrm{g} / \mathrm{g})\end{array}$ & Tacalcitol & $\begin{array}{l}\text { Randomized, } \\
\text { double- } \\
\text { blinded, } \\
\text { placebo- } \\
\text { controlled, } \\
\text { left-right } \\
\text { trial }\end{array}$ & $\begin{array}{l}\text { MEL+placebo: } 2 / 35 \\
(5.7 \%) \\
\text { MEL+tacalcitol: } 9 / 32 \\
(25.7 \%)>75 \% \\
\text { repigmentation after } \\
12 \text { treatments ( } 3 \\
\text { months) }\end{array}$ & Yes & \begin{tabular}{||l}
$($ Lu-yan, \\
Wen-wen \\
et al. 2006)
\end{tabular} \\
\hline
\end{tabular}




\begin{tabular}{|c|c|c|c|c|c|}
\hline Treatment & $\begin{array}{c}\text { Type of } \\
\text { Vitamin D }\end{array}$ & $\begin{array}{l}\text { Study } \\
\text { design }\end{array}$ & Results & Effect & References \\
\hline $\begin{array}{l}\text { Untreated vs } \\
\text { calcipotriol }\end{array}$ & Calcipotriol & $\begin{array}{l}\text { Prospective, } \\
\text { left/right } \\
\text { comparative, } \\
\text { open study }\end{array}$ & $\begin{array}{l}\text { 3/24: partial response } \\
\text { Of } 3 \text { patients showing } \\
\text { response } \\
\text { 1: } 5 \% \text { repigmentation } \\
\text { (only treated area) } \\
\text { 2: } 20 \% \\
\text { repigmentation (both } \\
\text { treated and untreated } \\
\text { areas) } \\
3: 30 \% \\
\text { repigmentation } \\
\text { (treated), } 10 \% \\
\text { repigmentation } \\
\text { (untreated) }\end{array}$ & No & $\begin{array}{l}\text { (Chiaverini, } \\
\text { Passeron } \\
\text { et al. 2002) }\end{array}$ \\
\hline $\begin{array}{l}\text { Betamethasone } \\
\text { vs } 0.005 \% \\
\text { calcipotriol vs } \\
\text { betamethasone/ } \\
\text { calcipotriol }\end{array}$ & Calcipotriol & $\begin{array}{l}\text { Randomized, } \\
\text { non-placebo } \\
\text { controlled } \\
\text { study }\end{array}$ & $\begin{array}{l}\text { All groups: no } \\
\text { patients }>75 \% \\
\text { repigmentation } \\
\text { Betamethasone: } 2 / 15, \\
\text { Calcipotriol: } 1 / 15, \\
\text { Betamethasone/ } \\
\text { calcipotriol: } 4 / 15 \text { 50- } \\
75 \% \text { repigmentation } \\
\text { Time to } \\
\text { repigmentation was } \\
\text { faster in combination } \\
\text { treatment }\end{array}$ & $\begin{array}{c}\text { No } \\
\text { (alone) } \\
\text { Yes } \\
\text { (combi- } \\
\text { nation) }\end{array}$ & $\begin{array}{l}\text { (Kumaran, } \\
\text { Kaur et al. } \\
2006)\end{array}$ \\
\hline $\begin{array}{l}\text { NB-UVB thrice } \\
\text { weekly vs NB- } \\
\text { UVB+ } \\
\text { calcipotriol } \\
(0.05 \%)\end{array}$ & Calcipotriol & $\begin{array}{l}\text { Randomized, } \\
\text { non-placebo } \\
\text { controlled } \\
\text { study }\end{array}$ & $\begin{array}{l}\text { NB-UVB: } 10 / 24 \\
(41.67 \%) \\
\text { NB-UVB }+ \\
\text { calcipotriol: } 6 / 13 \\
(46.2 \%) 50-100 \% \\
\text { repigmentation after } \\
30 \text { treatments } \\
\text { (10weeks) }\end{array}$ & No & $\begin{array}{l}\text { (Arca, } \\
\text { Tastan } \\
\text { et al. 2006) }\end{array}$ \\
\hline $\begin{array}{l}\text { PUVA+placebo } \\
\text { vs PUVA+ } \\
\text { calcipotriol } \\
(0.05 \mathrm{mg} / \mathrm{g}- \\
0.005 \%)\end{array}$ & Calcipotriol & $\begin{array}{l}\text { Randomized, } \\
\text { double- } \\
\text { blinded, } \\
\text { placebo- } \\
\text { controlled, } \\
\text { left-right } \\
\text { trial }\end{array}$ & $\begin{array}{l}\text { PUVA+placebo: } \\
30.07 \pm 1.34 \text { treatments } \\
\text { PUVA+calcipotriol: } \\
27.4 \pm 1.47 \text { treatments } \\
\text { (time to complete } \\
\text { repigmentation) }\end{array}$ & Yes & $\begin{array}{l}\text { (Ermis, } \\
\text { Alpsoy } \\
\text { et al. 2001) }\end{array}$ \\
\hline
\end{tabular}




\begin{tabular}{|c|c|c|c|c|c|}
\hline Treatment & $\begin{array}{c}\text { Type of } \\
\text { Vitamin D }\end{array}$ & $\begin{array}{l}\text { Study } \\
\text { design }\end{array}$ & Results & Effect & References \\
\hline $\begin{array}{l}\text { PUVAsol+ } \\
\text { placebo vs } \\
\text { PUVAsol+calci } \\
\text { potriol } \\
(50 \mu \mathrm{g} / \mathrm{g}-0.005 \%)\end{array}$ & Calcipotriol & $\begin{array}{l}\text { Randomized, } \\
\text { double- } \\
\text { blinded, } \\
\text { placebo- } \\
\text { controlled, } \\
\text { left-right } \\
\text { trial }\end{array}$ & $\begin{array}{l}\text { PUVAsol+placebo: } \\
\text { 9/17 (52.9\%) } \\
\text { PUVAsol+calcipotriol: } \\
13 / 17(76.5 \%)>75 \% \\
\text { repigmentation after } \\
18 \text { months }\end{array}$ & Yes & $\begin{array}{l}(\text { Parsad, } \\
\text { Saini et al. } \\
1998)\end{array}$ \\
\hline $\begin{array}{l}\text { Excimer laser } \\
\text { thrice week vs } \\
\text { excimer laser } \\
+ \text { calcipotriol } \\
(0.005 \%)\end{array}$ & Calcipotriol & $\begin{array}{l}\text { Randomized, } \\
\text { single- } \\
\text { blinded, left- } \\
\text { right trial }\end{array}$ & $\begin{array}{l}\text { Excimer: } 22 \% \\
\text { Excimer +calcipotriol: } \\
23 \% \text { mean } \\
\text { repigmentation after } \\
8 \text { weeks }\end{array}$ & No & $\begin{array}{l}\text { (Goldinger, } \\
\text { Dummer } \\
\text { et al. 2007) }\end{array}$ \\
\hline $\begin{array}{l}\text { Excimer laser } \\
\text { twice a week vs } \\
\text { excimer laser } \\
\text { +high } \\
\text { concentration of } \\
\text { tacalcitol }\end{array}$ & $\begin{array}{l}\text { High } \\
\text { concentration } \\
\text { of tacalcitol }\end{array}$ & $\begin{array}{l}\text { Randomized, } \\
\text { single- } \\
\text { blinded, left- } \\
\text { right trial }\end{array}$ & $\begin{array}{l}\text { Excimer vs Excimer + } \\
\text { tacalcitol: no } \\
\text { significant difference }\end{array}$ & No & $\begin{array}{l}(\mathrm{Oh}, \mathrm{Kim} \\
\text { et al. 2011) }\end{array}$ \\
\hline
\end{tabular}

$\mu \mathrm{g} / \mathrm{g}$ : microgram/gram, vs: versus, NB-UVB: narrowband ultraviolet B, MEL: monochromatic excimer light, PUVA: psoralen and ultraviolet A, mg/g: milligram/gram, PUVAsol: psoralen and sun exposure

Table 1. Randomized, controlled studies regarding the effect of vitamin D on the treatment of vitiligo

Vitamin D analogues as monotherapy are less effective than topical corticosteroids in vitiligo, although there is some evidence of an additive effect with combining the two. (Hossani-Madani and Halder 2011) There is no convincing evidence to suggest that topical vitamin D analogues in combination with phototherapy, i.e., narrowband UVB (NB-UVB), psoralen and ultraviolet A (PUVA), or 308 nanometer (nm) excimer laser, are superior to phototherapy alone. Gawkrodger et al. recommended that topical vitamin D analogues in combination with NB-UVB or PUVA therapy should not be used in the treatment of vitiligo.(Gawkrodger, Ormerod et al. 2008)

\section{Conclusion}

Vitiligo is generally considered to be an autoimmune disorder. There is preliminary evidence that vitamin $\mathrm{D}$ deficiency could be causally related to a variety of autoimmune diseases. There have been some reports showing good responses to topical vitamin D analogues alone or as part of combination treatment with phototherapy. However, future studies are required to evaluate the relationship of serum vitamin D levels and vitiligo, as well as to elucidate the effects of vitamin $\mathrm{D}$ in vitiligo. The utility of topical vitamin $\mathrm{D}$ agents in the treatment of vitiligo also needs to be substantiated. 


\section{References}

Adorini, L. and G. Penna (2008). "Control of autoimmune diseases by the vitamin D endocrine system." Nat Clin Pract Rheumatol 4(8): 404-412.

Arca, E., H. B. Tastan, et al. (2006). "Narrow-band ultraviolet B as monotherapy and in combination with topical calcipotriol in the treatment of vitiligo." J Dermatol 33(5): 338-343.

Baeke, F., E. van Etten, et al. (2008). "Vitamin D signaling in immune-mediated disorders: Evolving insights and therapeutic opportunities." Mol Aspects Med 29(6): 376387.

Birlea, S. A., G. E. Costin, et al. (2008). "Cellular and molecular mechanisms involved in the action of vitamin D analogs targeting vitiligo depigmentation." Curr Drug Targets 9(4): 345-359.

Birlea, S. A., G. E. Costin, et al. (2009). "New insights on therapy with vitamin D analogs targeting the intracellular pathways that control repigmentation in human vitiligo." Med Res Rev 29(3): 514-546.

Bouillon, R., G. Carmeliet, et al. (2008). "Vitamin D and human health: lessons from vitamin D receptor null mice." Endocr Rev 29(6): 726-776.

Cantorna, M. T., C. E. Hayes, et al. (1998). "1,25-Dihydroxycholecalciferol inhibits the progression of arthritis in murine models of human arthritis." J Nutr 128(1): 6872.

Cantorna, M. T., C. Munsick, et al. (2000). "1,25-Dihydroxycholecalciferol prevents and ameliorates symptoms of experimental murine inflammatory bowel disease." J Nutr 130(11): 2648-2652.

Cantorna, M. T., S. Yu, et al. (2008). "The paradoxical effects of vitamin D on type 1 mediated immunity." Mol Aspects Med 29(6): 369-375.

Chen, S., G. P. Sims, et al. (2007). "Modulatory effects of 1,25-dihydroxyvitamin D3 on human B cell differentiation." J Immunol 179(3): 1634-1647.

Chiaverini, C., T. Passeron, et al. (2002). "Treatment of vitiligo by topical calcipotriol." J Eur Acad Dermatol Venereol 16(2): 137-138.

Daniel, C., N. A. Sartory, et al. (2008). "Immune modulatory treatment of trinitrobenzene sulfonic acid colitis with calcitriol is associated with a change of a $\mathrm{T}$ helper (Th) 1/Th17 to a Th2 and regulatory T cell profile." J Pharmacol Exp Ther 324(1): 2333.

Ermis, O., E. Alpsoy, et al. (2001). "Is the efficacy of psoralen plus ultraviolet A therapy for vitiligo enhanced by concurrent topical calcipotriol? A placebo-controlled doubleblind study." Br J Dermatol 145(3): 472-475.

Gawkrodger, D. J., A. D. Ormerod, et al. (2008). "Guideline for the diagnosis and management of vitiligo." Br J Dermatol 159(5): 1051-1076.

Goldinger, S. M., R. Dummer, et al. (2007). "Combination of 308-nm xenon chloride excimer laser and topical calcipotriol in vitiligo." J Eur Acad Dermatol Venereol 21(4): 504508.

Hossani-Madani, A. and R. Halder (2011). "Treatment of vitiligo: advantages and disadvantages, indications for use and outcomes." G Ital Dermatol Venereol 146(5): 373-395. 
Jurutka, P. W., L. Bartik, et al. (2007). "Vitamin D receptor: key roles in bone mineral pathophysiology, molecular mechanism of action, and novel nutritional ligands." J Bone Miner Res 22 Suppl 2: V2-10.

Klaus Wolff, L. G., Stephen Katz, Barbara A. Gilchrest, Barbara Gilchrest, Amy Paller, David J. Leffell, David Leffell (2008). Fitzpatrick's Dermatology in General Medicine. New York, McGraw-Hill Medical.

Kriegel, M. A., J. E. Manson, et al. (2011). "Does vitamin D affect risk of developing autoimmune disease?: a systematic review." Semin Arthritis Rheum 40(6): 512531 e518.

Kumaran, M. S., I. Kaur, et al. (2006). "Effect of topical calcipotriol, betamethasone dipropionate and their combination in the treatment of localized vitiligo." J Eur Acad Dermatol Venereol 20(3): 269-273.

Lemire, J. M. and D. C. Archer (1991). "1,25-dihydroxyvitamin D3 prevents the in vivo induction of murine experimental autoimmune encephalomyelitis." J Clin Invest 87(3): 1103-1107.

Leone, G., A. Pacifico, et al. (2006). "Tacalcitol and narrow-band phototherapy in patients with vitiligo." Clin Exp Dermatol 31(2): 200-205.

Loser, K., A. Mehling, et al. (2006). "Epidermal RANKL controls regulatory T-cell numbers via activation of dendritic cells." Nat Med 12(12): 1372-1379.

Lu-yan, T., F. Wen-wen, et al. (2006). "Topical tacalcitol and 308-nm monochromatic excimer light: a synergistic combination for the treatment of vitiligo." Photodermatol Photoimmunol Photomed 22(6): 310-314.

Mathieu, C., M. Waer, et al. (1994). "Prevention of autoimmune diabetes in NOD mice by 1,25 dihydroxyvitamin D3." Diabetologia 37(6): 552-558.

Montes, L. F., R. Pfister, et al. (2003). "Association of vitiligo with Sjogren's syndrome." Acta Derm Venereol 83(4): 293.

Niepomniszcze, H. and R. H. Amad (2001). "Skin disorders and thyroid diseases." J Endocrinol Invest 24(8): 628-638.

Oh, S. H., T. Kim, et al. (2011). "Combination treatment of non-segmental vitiligo with a 308$\mathrm{nm}$ xenon chloride excimer laser and topical high-concentration tacalcitol: a prospective, single-blinded, paired, comparative study." J Am Acad Dermatol 65(2): 428-430.

Parsad, D., R. Saini, et al. (1998). "Combination of PUVAsol and topical calcipotriol in vitiligo." Dermatology 197(2): 167-170.

Rodriguez-Martin, M., M. Garcia Bustinduy, et al. (2009). "Randomized, double-blind clinical trial to evaluate the efficacy of topical tacalcitol and sunlight exposure in the treatment of adult nonsegmental vitiligo." Br J Dermatol 160(2): 409-414.

Sehgal, V. N., V. L. Rege, et al. (1976). "Clinical pattern of vitiligo amongst Indians." The Journal of dermatology 3(2): 49-53.

Silverberg, J. I., A. I. Silverberg, et al. (2010). "A pilot study assessing the role of 25 hydroxy vitamin D levels in patients with vitiligo vulgaris." J Am Acad Dermatol 62(6): 937-941.

Spach, K. M., F. E. Nashold, et al. (2006). "IL-10 signaling is essential for 1,25dihydroxyvitamin D3-mediated inhibition of experimental autoimmune encephalomyelitis." J Immunol 177(9): 6030-6037. 
Van Etten, E., D. D. Branisteanu, et al. (2003). "Combination of a 1,25-dihydroxyvitamin D3 analog and a bisphosphonate prevents experimental autoimmune encephalomyelitis and preserves bone." Bone 32(4): 397-404.

van Etten, E. and C. Mathieu (2005). "Immunoregulation by 1,25-dihydroxyvitamin D3: basic concepts." J Steroid Biochem Mol Biol 97(1-2): 93-101. 


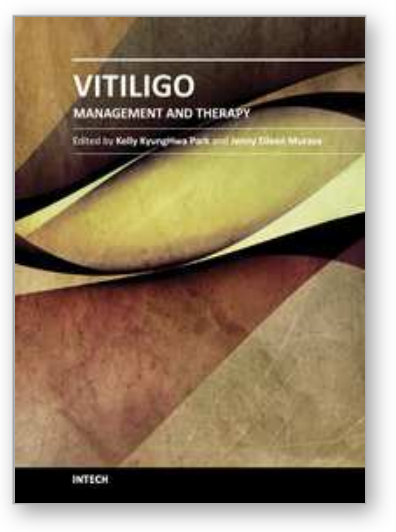

\author{
Vitiligo - Management and Therapy \\ Edited by Dr. Kelly KyungHwa Park
}

ISBN 978-953-307-731-4

Hard cover, 174 pages

Publisher InTech

Published online 14, December, 2011

Published in print edition December, 2011

Vitiligo: Management and Therapy is a practical guide to vitiligo that reflects current research related to the fundamentals of vitiligo and its management. Vitiligo experts and researchers from all over the world have contributed to this text, accounting for its comprehensive nature and diverse array of topics. The recent advances in medicine and technology have led to a better understanding of the disease and have broadened available treatment options. The essentials are captured in this book and are complemented by useful clinical photographs and reference tables. This concise tool will serve as an invaluable resource for clinicians in daily practice.

\title{
How to reference
}

In order to correctly reference this scholarly work, feel free to copy and paste the following:

Sang Ho Oh and Miri Kim (2011). Vitamin D and Vitiligo, Vitiligo - Management and Therapy, Dr. Kelly KyungHwa Park (Ed.), ISBN: 978-953-307-731-4, InTech, Available from:

http://www.intechopen.com/books/vitiligo-management-and-therapy/vitamin-d-and-vitiligo

\section{INTECH}

open science | open minds

\section{InTech Europe}

University Campus STeP Ri

Slavka Krautzeka 83/A

51000 Rijeka, Croatia

Phone: +385 (51) 770447

Fax: +385 (51) 686166

www.intechopen.com

\section{InTech China}

Unit 405, Office Block, Hotel Equatorial Shanghai

No.65, Yan An Road (West), Shanghai, 200040, China

中国上海市延安西路65号上海国际贵都大饭店办公楼 405 单元

Phone: +86-21-62489820

Fax: +86-21-62489821 
(C) 2011 The Author(s). Licensee IntechOpen. This is an open access article distributed under the terms of the Creative Commons Attribution 3.0 License, which permits unrestricted use, distribution, and reproduction in any medium, provided the original work is properly cited. 